\title{
六甲山地における土砂桨害について（その 1)*
}

\author{
低引洋隆**. 小橋澄治***. 羽原俊行**
}

\section{Studies on the Dabris-flow in Rokko District (Part 1)}

\author{
Hirotaka SOKOBIKI, Sumiji KOBASHI and Toshiyuki HABARA
}

\begin{abstract}
Slope failure and land-slide as geologic hazard have been studied in numerous districts up to the present based on the examinations of both the topographical and geological environments. Concerning debris flows, on the other hand, only a few researches have been reported from the same viewpoint. This is because the debris flow has been occurred in the relatively spreading space-time regions concerning topography and geology.

In this paper, debris flows occurred in Rokko district on July, 1967 were examined in detail based on the concept of "drainage system" from topographical and geological viewpoints. The results clearly indicate that the debris flow occurs at the null order streames and develops downstream systematically to the higher order one.
\end{abstract}

\section{1. まえがき}

大阪湾の北西縁に位置し，標高 $932.1 \mathrm{~m}$ の六甲山を 有する六甲山地は，その麓に幅 $2 \sim 4 \mathrm{~km}$ ，長さ $30 \mathrm{~km}$ にわたって，神戸市をはじめとする阪神間の諸都市を配 している。市街地から，六甲山地の山頂を望む仰角は $10^{\circ} \sim 20^{\circ}$ にもなり，急流河川が市街地に流入している。 六甲山地の基盤地質は大部分花崗岩類により構成され ている。この花崗岩類は, 六甲変動による断層破砕作用 を受け，さらに，風化作用をも受けたため，もろい岩質 となっている1)。

以上のような状況にある六甲山地は，市民にとっては 緑を身近かに提供してくれる惒いの場所でもある。その 反面一旦荒れると山腹から流れ出す水, 砂踏, 流木等に よる破壊力は，底知れぬるのがあるという恐ろしい山と もなる。六甲山地に関する土砂災害は有史以来（799 年 以来) 数十回記録され, 特に昭和 13 年荻害では, 流出 土砂量 500 600万 $\mathrm{m}^{3}$, 死者 616 名を出す大災害とな り，その後も集中豪雨の度に規模の大小はあるものの， 災害が頻発している2)。

\footnotetext{
* 昭和 56 年度応用地質学会研究発表会にて発表 *** 復建調査設計株式会社

*** 京都大学農学部
}

本論文は，これ等の荻害でも最も破壊力の大きいと考 えられる土石流災害を取り上げ，六甲山地全域（約 151 $\mathrm{km}^{2}$ ) を対象に, 地形, 地質条件と土石流発生状況との 関連性を, 昭和 42 年 7 月災害をモデル災害年とし考察 したものである。

\section{2. 六甲山地の地形・地質概要}

六甲山地は，図 1 に見られるごとく $932.1 \mathrm{~m}$ の最高標 高を有する六甲山より摩耶山 $(698.6 \mathrm{~m})$, 菊水山 $(458.9$ $\mathrm{m})$ から鉄拐山 $(260.0 \mathrm{~m})$ に至る $\mathrm{NE} \sim \mathrm{SW}$ 方向に延び る山体である。この山体は東に高く，西に次第に低くな る傾動地塊豆となっている。一方, 海岸平野に向かって は急崖をなし（図 2), 北側及び西側では緩く傾斜し, 台地状の地形を呈している。これらの複雑な地形は, 東 西方向の圧縮応力による地殼変動, 特に断層運動によっ て形成されたものである。海岸平野部の急崖性の地形 は, 約 20〜30 万年前から活発化したとされる NE〜SW 系の大断層, つまり甲陽断層, 芦屋断層, 五助橋断層, 湯槽谷断層等により，それぞれ 200〜300 m の落差を生 じ形成したものである ${ }^{3}$ (図 $2 ， 3 ４$ 参照)。

六甲山地の地質分布は図 3 に示されている。六甲山地 を構成する地質は, 主に山地部に分布する基盤岩類と, 主に山麓部に分布する被覆層とに大別される。基盤岩類 


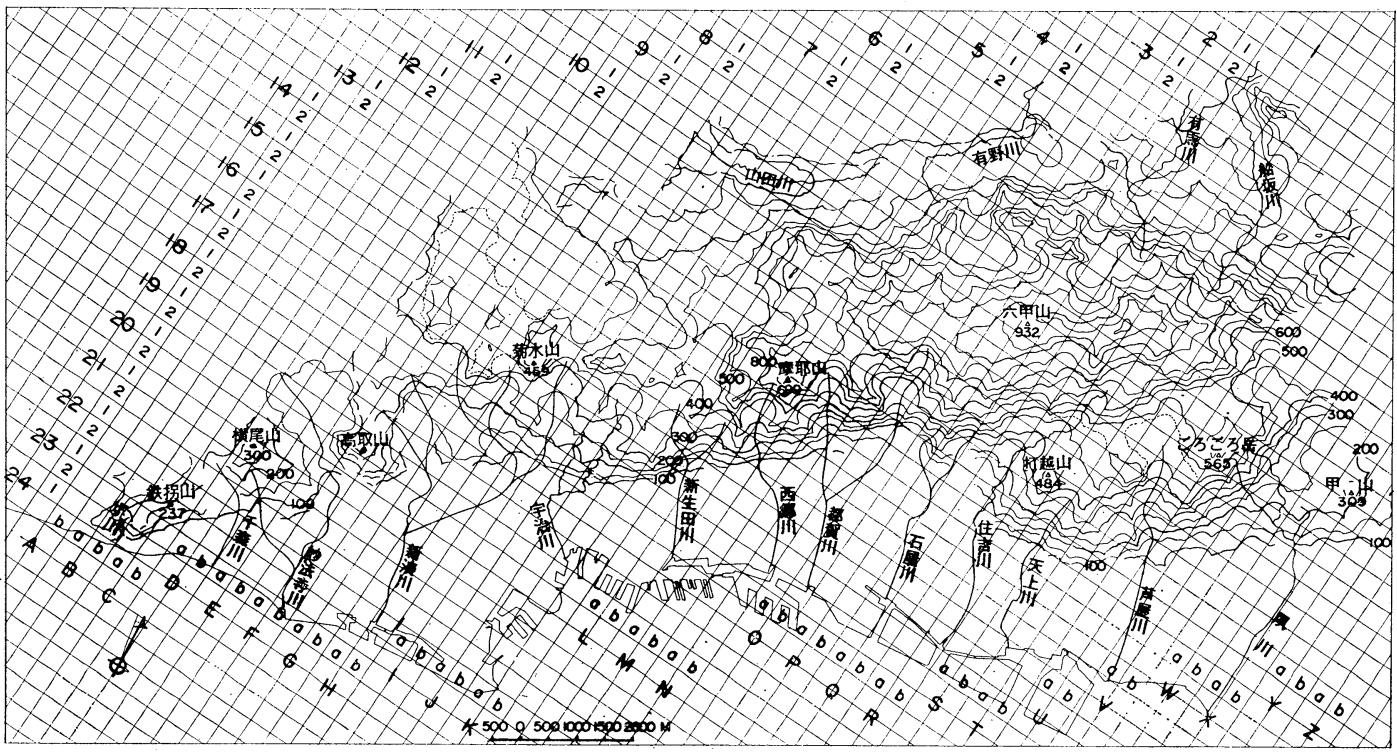

図 1 六甲山地の接峯面図 (メッシュ内の数字と英字を組み合せて各メッシュの記号とする)

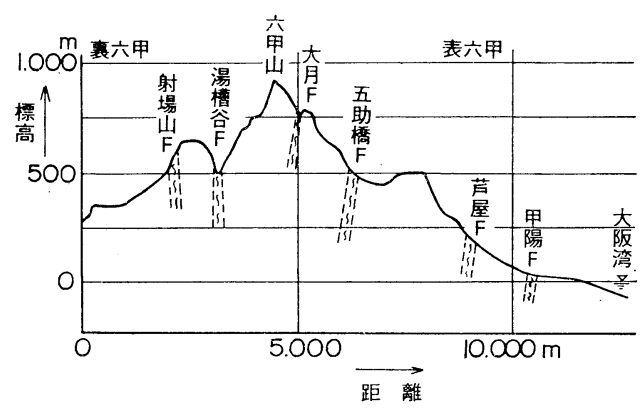

図 2 六甲山地の地形断面と断層

は, 古いものから古生層, 布引花崗閃緑岩, 有馬層群, 土橋石英閃緑岩，六甲花崗岩である。このらち布引花崗 閃緑岩と六甲花崗岩が六甲山地の大半を占める。古生層 は, 花崗岩体中に浮かんだような状態3で分布し, ホル ンフェルス化した砂岩・頁岩の互層よりなる。布引花崗 閃緑岩は六甲南縁に分布し，一般に完晶質で石英，長石 などの優白色の鉱物と，角閃石，黒雲母などの有色鉱物 からなり，しばしば直径数センチ〜数十七ンチの黒色球 状の捕獲岩を有する。この岩体は, 中央構造線の北側に 広く分布する領家帯の花崗岩類に相当するものとされて いる。有馬層群は，中期白亜紀の流紋岩質凝灰岩，凝灰 角礫岩を主体とする，堅硬緻密な岩石である。土橋石英 閃緑岩は六甲山西南に局部的に分布し，針状結晶の角閃 石を含む細粒な石英閃緑岩である。六甲花崗岩は六甲山 地で最も広く分布し, 石英, 正長石, 黒雲母を主成分鉱
物とする。六甲花崗岩は構成粒子の大きさにより，細粒 〜粗粒花崗岩に分類されている ${ }^{3)}$ 。大部分は中〜粗粒花 崗岩であるが，六甲山頂付近に細粒花崗岩が広く分布し ている。これ等花崗岩類は一般に強く風化し，いわゆる まさ土化している場合が多い。特に，侵食小起伏面でま さ土が厚く分布している。また断層破砕帯に沿っても風 化が進み軟岩・まさ土状になっている。これ等基盤岩類 を覆う被覆層は，ほぼ水平な層理面を有する砂岩・砅岩 互層内に，比較的連続性の良い数枚の凝灰岩ない儿凝灰 質泥岩を挟む第三紀中新世の神戸層群，碩層を主体とす る第三紀鮮新世〜第四紀更新世の大阪層群，段丘層，括 よび礫，砂，粘土よりなる完新世の沖積層である。

\section{3. 地形・地質特性の記載}

今回の研究対象域は図 1 のごとく, 西は境川, 東は夙 川就よび船坂川, 北は山田川, 有野川, 南は市街地と山 地部との境界で囲まれる地域で，その面積は約 $151 \mathrm{~km}^{2}$ である。広範な面積を対象に，ある現象（今回の場合は 崩壊および土石流）とその素因となる各種条件との相関 性を求める場合, ぞの程度のスケールで考觉るか，そし て対象域全体に同じ精度の情報が得られるかは重要であ る。本研究においてはこの点に留意し, 以下の方法で地 形・地質特性の記載を行った。

1) 基本地形図

対象域全てをカバーする最も大縮尺の地形図は縮尺 1/25,000であった。しかし，これでは崩壊・土石流の 

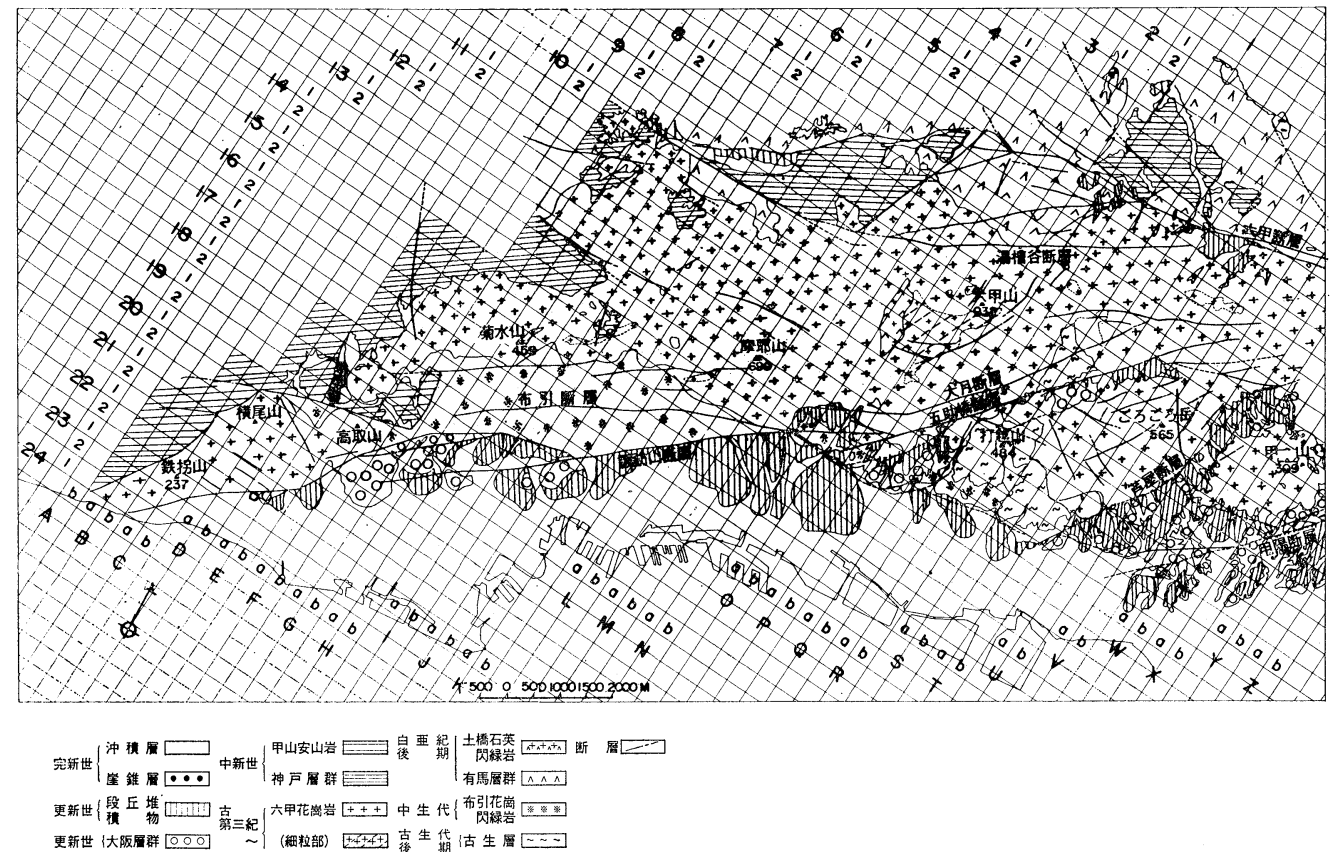

図 3 六甲山地の基盤地質図

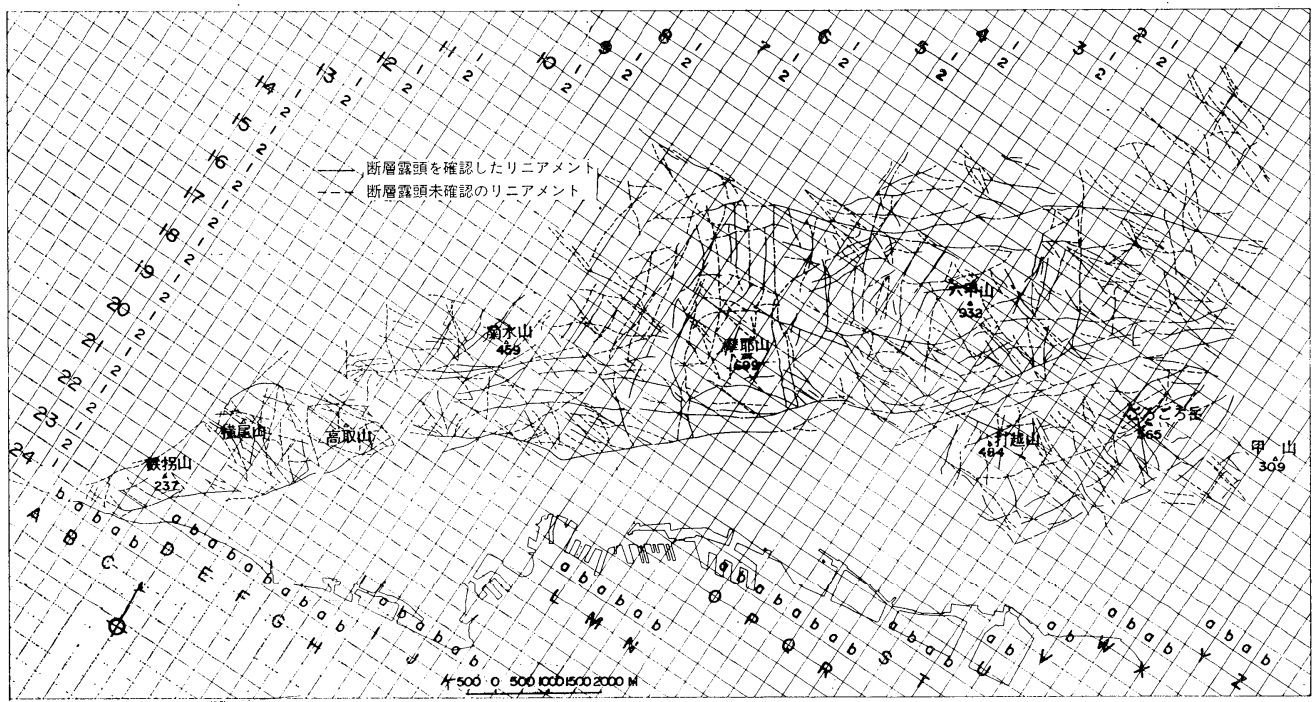

図 4 六甲山地のリニアメント（実線は断層露頭を確認したリニアメント，点線は断層露頭未確認 のリニアメント)

発生状況が正確に記載出来ず，また，微地形特性が読み 取れない。そこで, 神戸市発行の縮尺 1/10,000 地形図 と芦屋市域の縮尺 1/5,000 写真地図（国土地理院作成） を縮尺 $1 / 10,000$ にコンパイルした地形図を基本地形図 とした。
2) 航空写真

本研究で対象とする崩壊・土石流は昭和 42 年 7 月に 発生したものである。状況は，昭和 41 年 5 月撮影（白 黒, 縮尺 $1 / 10,000$ ), 昭和 42 年 7 月撮影（白黒, 縮尺 1/10,000）の航空写真判読により把握した。なお, 現況 
そついては昭和 50 年撮影（カラー，縮尺 $1 / 10,000$ ）の 航空写真の判読によって把握した。このように，本研究 で取扱った崩壊・土石流現象は，精度的には全域にわた って均一に記録されているが，いわゆる“形態的パター ンとして認識した崩壊・土石流現象”であることを強調 しておく。

\section{3) 水系図}

昭和 41 年 5 月撮影の航空写真より凹地形部を判読識 別し，基本地形図に移写し水系図を作成した。最上流の 水系を 0 次とし，Strahler の次数らけけ準じて下流に行 くにしたがい1次, 2 次, $\cdots \cdots, n$ 次の水系とした ${ }^{4)} 。 一$ 般に砂防の分野では水系の定義を, 縮尺 $1 / 25,000$ ない 乙 $1 / 50,000$ 地形図で谷幅 $(W)$ と谷長 $(L)$ の比 $(L / W)$ が 1 以上のものを水系とし，最上流のそれを 1 次として いるが，これは今回作成した水系のほぼ 2 次に相当す る。

4）流域荒廃現況図

昭和 42 年災害の前と後について，それぞれ崩壊跡地， 流下域, 堆砂域, ダム, 秃楮地注1), 岩塔注2) の航空写真 判読を行い記載した。

5）地形分類図

基本地形図を 1/25,000 に縮小し，接峯面図（図-1), 起伏量図, 傾斜区分図を作成した。接峯面図は, $50 \mathrm{~m}$ 二 ンターごとについて，500 m の谷を埋める方法で作成し た。起伏量図は $1 \mathrm{~km}$ 方眼について, 最高点と最低点と の差を求め, 方眼の中心に数值を与兄る方法をとった ${ }^{5)}$ 。 傾斜区分図は，ホートン法に基づいて作成した ${ }^{4), 5) 。 こ ~}$

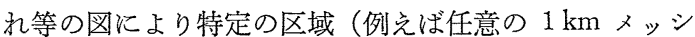
二内）の平均的な地形情報が得られる。

6）基盤地質図（図-3）

基本地形図を縮小した $1 / 25,000$ 地形図に既存の地質 図を使ってコンパイルした。な招，地質境界，断層の位 置等に関しては若干の踏査資料で正確を期した。

7）リニアメント図 (図-4)

六甲山地のリニアメントは，土地条件図の付図 32 と して発表されている6)。ただし，この図は，主に表六甲 を対象にしたものである。そこで今回は，まずこれを航 空写真で確認しながら地形図（縮尺 $1 / 25,000$ ） 飞移写 し，続いてこれと同じ基準でもって空白部のリニアメン トを描いた。記載した「直線構造」(リニアメント十破 砕線）の長さは，約 $200 \mathrm{~m}$ 以上である。六甲山地のリ

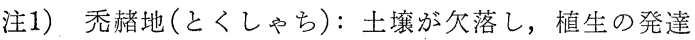
が極めて悪い，いわゆるハグ地。

注2）岩塔：急傾斜した露岩地で，岩壁のように連続し たものでなく，塔状に突き出た地形をいう。
ニアメントは, 多くの場合, 新鮮な断層粘土と, 侵食に 弱い破碑带を伴う断層である。方向としては，NE〜SW 系と WNW ESE 系とほぼ $\mathrm{E} \sim \mathrm{W}$ 系のものが加わっ て全体のパターンが形作られている。

8）表層現況図

昭和 50 年撮影の航空写真を使用し，流域の荒廃状況， 溪床堆積物あるいは崖錐堆積物の分布, 段丘層, 大阪層 群の分布, 深層風化帯の分布, 秃赫地 - 岩塔の分布, 土 地利用状況等について判読・記載を行った。ここでいら 深層風化帯 (10 m 以上) は, 柿谷による風化分帯の $\mathrm{C}_{1}$ $\mathrm{C}_{3}$ (化学的風化帯) 飞相当する7)。

\section{4. 地形・地質特性と土石流の発生}

地形，地質特性に関する基礎データをもとに，六甲山 地ではどのような地形・地質条件のところで土石流が発 生し易いかを検討した。

\section{1 土石流発生溪流}

土石流の発生を検討する場合，何をもって発生とする かは非常に重要なことである。一般的に土石流とは，土 石と水が一体となって，大きな岩塊を先頭に回転，転動 しながら流下する現象といわれている8)。発生後の航空 写真上では，当然のことながら流下の痕跡としてしか認 められず，厳密にはどこから土石流の形態を取り始めた のか（発生したのか）は判断されない。一つの考光とし て，土石流の発生を高橋のいら水理学的条件にもとづく 渓床堆積物の流動化 ${ }^{9}$ としてとらえれば，航空写真上の 流下痕跡の最上流端を対象に議論することが可能とな る。

しかし，位川流域の土石流調査 ${ }^{10)}$ でも指摘されてい るが，六甲山地に执いても流下痕跡の最上流端にはスプ ーン状の崩壊跡地がしばしば認められ，必ずしも崩壊跡 地を土石流の発生としてとら学ることはできない。そこ で本章では，2 次の渓流を単位とし，その出口に流下の 痕跡が認められた場合を土石流の発生渓流として取り扱 ら。

六甲山地の 2 次渓流数は 1,044 個所で，昭和 42 年 7 月災害時の土石流発生は 248 渓流であった。発生渓流で の流下パターンを分類すると 図-5 のようになる。この 図で黒く塗色した所は崩壊地を表し，ほとんどの溪流で 流下痕跡の最上流端に崩壊地が認められ，六甲山地に特 ける特徵的な土石流発生パターンを示している。I は, 明膫な崩壤地が認められ, 溪流出口に流下痕跡の認めら れるパターンである。IIは, 明瞭な崩壊地が最上流端に 認められないものの, 渓流出口に流下痕跡の認められる パターンである。正は, 植生のために渓流出口で流下痕 


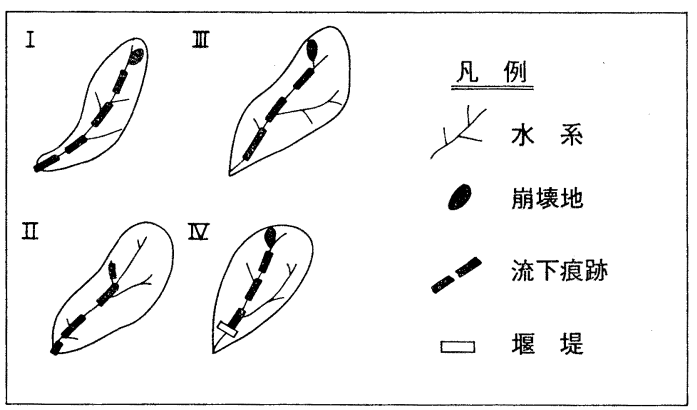

図-5 土石流発生 2 次渓流の流下パターン
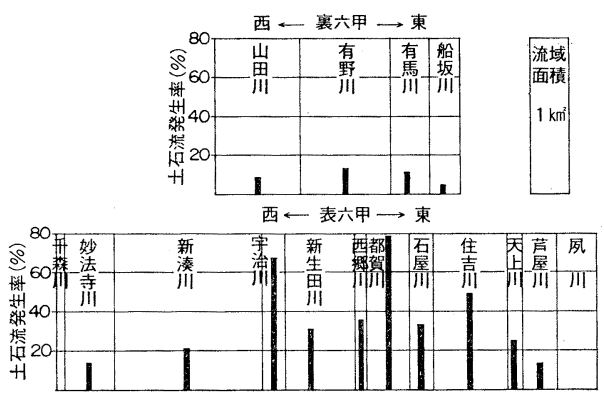

図-6 河川流域別の土石流発生率（昭和 42 年 7 月災 害)

跡を判読し切れないが，上流および下流の状況より判断 して発生渓流とした。IVは，流域内にダムがありそこで 土石流が停止しているもので，これも発生渓流とした。

全 2 次渓流に対する発生比率は $23.8 \%$ であり, 各河 川流域別にみると図-6 のよらになる。この図よりする と, 裏六甲に較べ表六甲での発生率が高く, 表六甲でも 中部〜東部にかけて土石流が多く発生し, 地域特性を反 映しているものと考完られる。

\section{2 地形・地質特性と土石流発生}

土石流が発生するためには，渓床に土石が推積し，そ れを動かす水理条件が満足されないといけない。とこ で, 流域の地形・地質特性として, 流域面積, 流域平均 勾配, 比高（流域内に括ける最高標高と最低標高との 差), 0 次渓流谷数, 基盤地質, リニアメント, 基盤岩の 風化状況を取り上げ，土石流発生との関連を調べた。こ こで取り上げた項目は, 土石流の発生・非発生について の判別解析（数量化II類）に括いて重要とされた，上位 7 項目に相当する ${ }^{11)}$ 。今回得られた結果を図-7〜図-14 に示した。な特，ここで対象とした 2 次渓流は, 発生・ 非発生渓流から各 150 渓流をサンプル抽出（等間隔抽出 法：サンプリング精度については分散和よび平均值に関 する検討を行っている）したものである ${ }^{12) 。 ~}$

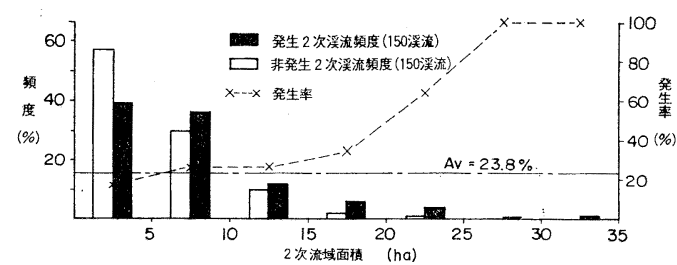

図-7 流域面積と土石流発生率

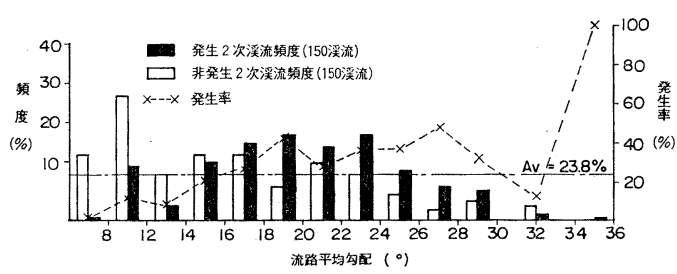

図-8 流路平均勾配と土石流発生率

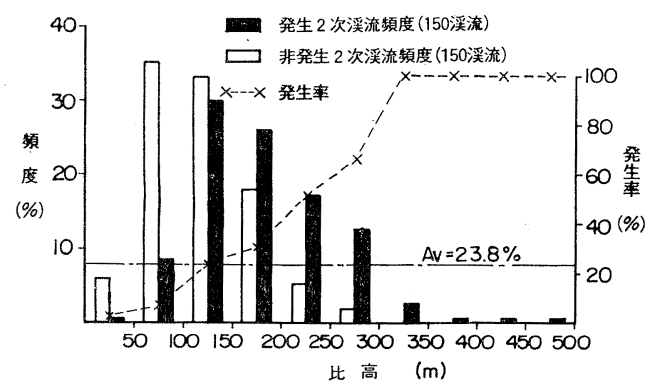

図-9 比高と土石流発生率

図-7 よりすると，流域面積が大きくなると発生し易 くなり，5１0 ha 以上になるとその傾向が強くなる。 しかし，両グループ（発生・非発生渓流）を判別するに は，15 20 ha 以上の渓流（発生率 $58 \%$ と高い）が全 渓流数の約 $5 \%$ しかなく, 流域面積単独では有効な要 因とはならない。

図-8 は, 主流路の平均勾配を両グループについて比 較したものである。平均勾配が $16^{\circ} \sim 18^{\circ}$ 以上になると

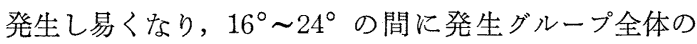
$55 \%$ が集中している。一般に $15^{\circ}$ 以上が土石流発生区 間とされて和り ${ }^{13)}$ ，六甲山地に特いてもこれがあてはま る。しかし，非発生グループでも比率としては低いもの の平均勾配の大きい渓流がある。これは平均勾配以外の 要因を考慮すべきことを表している。

図-9 は，流域内の最高点と最低点との差を此高とし， 両グループの比較をしたものである。両グループは, 150〜200 m を境に傾向を異にしている。非発生グルー プは $150 \sim 200 \mathrm{~m}$ 以下の割合が全体の $75 \%$, 発生グル ープは, 150〜200 m 以上の割合が $61 \%$ となっている。 
比高が大きく晾ると土石流を発生させ易くなるとい兄 る。比高は, 上述の流域面積, 流路平均勾配が溪流の流 出形態を直接支配する単要因であるのに対し, 流域全体 の流出形態捛よび斜面特性を加味した総合特性を示すと いえる。特に，斜面特性として比高の大きいことは流域 全体の山腹勾配が大きいことを表し, 溪床への土石の供 給量が多いものと考兄られる。

図-10 は，流域内の 0 次渓流数について，両グループ の傾向を見たものである。0次渓流は谷頭部の斜面内に 上流端を有する溪流で，一般に急峻である。この斜面は 崩壊を起因としてより多く侵食され，後退していると考 えられる。このような状況は, 六甲山地の侵食小起伏面 直下の谷頭部で明膫に現れ，馬蹄型の平面形状をした谷 型斜面に多数の崩壊地を有している。したがって，流域 内に 0 次渓流の数が多い程, 渓床へ土石をより多く供給 するであろうし，また崩壊が土石流発生のトリガーとし ての役目を果たすと考兄られる。0次溪流数が 20〜30 本以上になると発生グループの頻度は高くなり，上述の 傾向が強くなることが理解できる。しかし，20３0 本 以上の発生率は $42 \%$ と高いが，この範囲の渓流数は全 体の 2 割にも満たず，発生・非発生の判別をこの要因だ けで行うことは無理である。

図-11 は，渓流の代表的な地質（半分以上の面積を占 める地質）毎に両グループの頻度を示したものである。

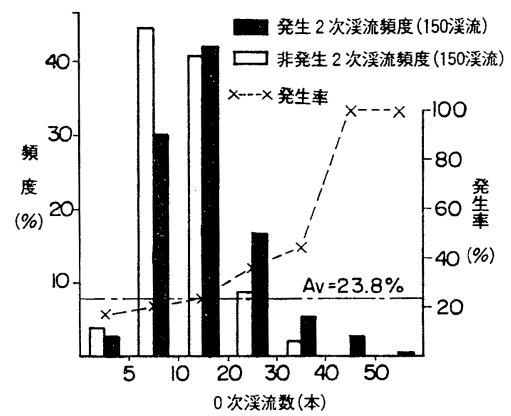

図-10 0 次溪流数と土石発生率

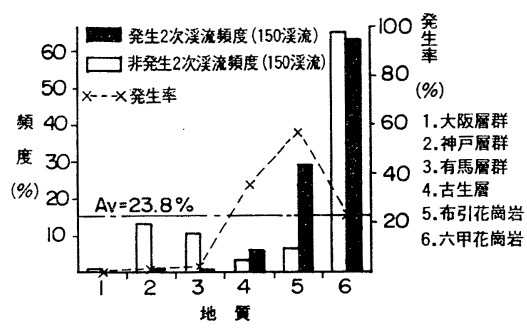

図-11 地質と土石流発生率
発生グループの大半を花崗岩類で占め, 六甲山地の土石 流が花崗岩類と密接な関係にあることを裏付けている。 しかし，六甲花崗岩については非発生の割合も非常に高 く，六甲山地での分布面積が広いことを表し，発生数は 多いが必ずしも発生率が高い（23.3\%）とはい党ない。 布引花崗閃緑岩については明らかに発生し易い（発生率 は $57.8 \%$ ）とい方る。布引花崗閃緑岩は有色鉱物の多 い花崗閃緑岩を主体とし，六甲花崗岩上りも風化され易 く, 山腹斜面に多くのささ土が分布している。布引花崗 閃緑岩の代表分布域は宇治川流域である。諏訪山断層以 北には侵食小起伏面が広く分布し，この面に厚くまさ土 が分布し，谷頭侵食が盛んに行われ，溪床に土石（粗粒 砂が多い）を供給している。谷頭侵食の激しさについて は，六甲山地の流域面積 $1 \mathrm{~km}^{2}$ 当り 0 次渓流数の平均 が 135 本 $/ \mathrm{km}^{2}$ に対し，宇治川流域では 235 本 $/ \mathrm{km}^{2}$ と非 常に多い点でも首肯できよう。ちなみに六甲花崗岩の代 表的分布域である住吉川流域では 144 本 $/ \mathrm{km}^{2}$ である。

図-12 は，溪流内に何本のリニアメントが存在するか を両グループについて示したものである。六甲山地にお。 けるリニアメントは，断層破砕帯と良く一致して招り， リニアメントの周辺部では土砂供給が盛んであることが 推定される。図上りすると、リニアメントの存在しない 渓流では，発生率が非常に小さく $(11 \%)$, 逆にリニア メントが 3 本以上の渓流では高く（約 40\%）なってい

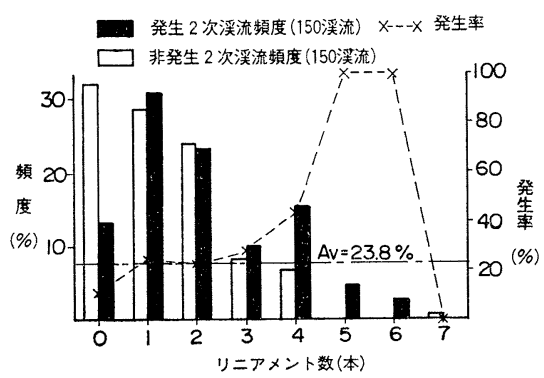

四-12 リニアメント数と土石流発生率

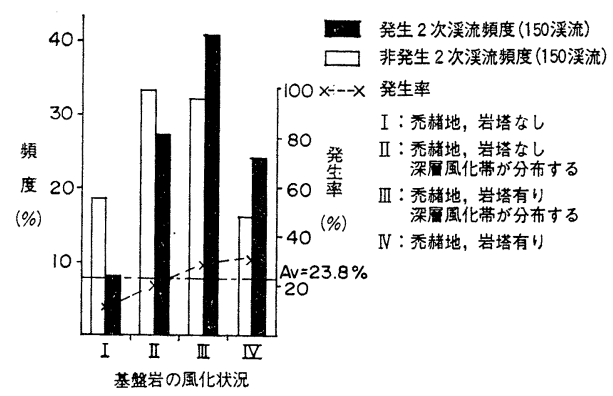

図-13 基盤岩の風化状況と土石流発生率 
る。しかし，どのようなメカニズムで発生し易いのかに ついては今後の問題で, リニアメント長あるいは断層破 砕帯の性状との関係を調べる必要がある。

図-13 は, 基盤岩の風化状況と両グループの傾向とを 比較したものである。ここでは, 風化状況の要因とし て, 渓流内に深層風化帯が分布しているか, 秃赫地・岩 塔が分布しているかを問題とした。秃赫地・岩塔もな く, 深層風化帯も分布しない渓流の発生率は非常に小さ く(約 $12 \%$ ), 秃赫地・岩塔のある溪流で発生率が比較 的高く（約 30\%）なっている。秃赫地・岩塔のある代 表的地域である住吉川黒岩谷では, 特異な土砂磁の供給 パターン（崖錐状，コーン状）が見られ，秃楮地・岩塔 を有する斜面直下に多量の岩屑を集積させ，これが土石 流発生酒関係する場合が市ると考光られる。深層風化帯 の分布状況で見ると, 分布する場合の発生率は $24 \%$, しない場合で $22 \%$ となっている。しかしこの要因に関 しては, 渓流と深層風化帯の分布との相対的位置が問題 となる。そこで深層風化帯が分布する全溪流について， 流路平均勾配との相関を取ると，図-14 に示す点線のよ うな発生率となり，同じ方法で深層風化帯の分布しない 場合の発生率は鎖線のようになる。このように流路平均 勾配が大きくなると発生率は高くなり, 深層風化帯が分 布していると，その傾向が一層強くなる。

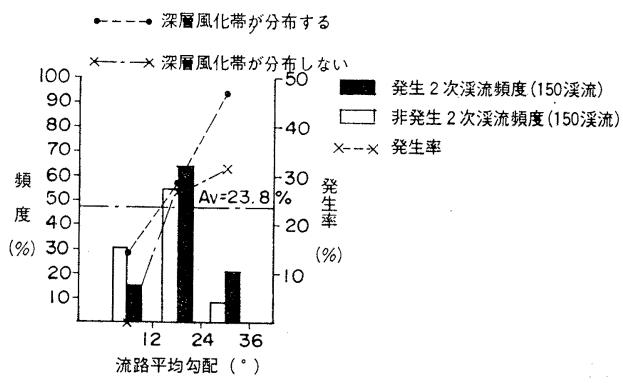

図-14 深層風化帯の分布状況と土石流発生率

\section{5. 土石流の流下様式}

昭和 42 年 7 月災害直後の航空写真判読によれば，谷 頭あるいは山ひだでの崩壞が多く認められ，その崩壊地 からの土砂移動はより高次の溪流へ連続するといらパタ

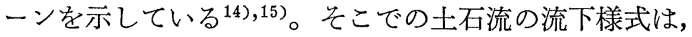
水系次数という基本的地形特性をべースに考学ることが できる。水系図をもとに六甲山地の代表的な流域につい て水系の分岐比を調べると，表-1 のようになる。この 表よりいずれの流域もほ注同程度の分岐比となって拈り 平均的には 0 次 $: 1$ 次 : 2 次水系の比率は $21: 4.5: 1$ で
表-1 六甲山地の代表河川流域における谷分岐 比及び土石流の発生率，流下率

\begin{tabular}{|c|c|c|c|c|c|c|c|c|c|}
\hline & \multicolumn{2}{|c|}{$\begin{array}{l}\text { 谷分 此 } \\
N(n) / N(n+1)\end{array}$} & \multicolumn{3}{|c|}{$\begin{array}{l}\text { 発 生 率 } \\
P(n) \%\end{array}$} & \multicolumn{2}{|c|}{$\begin{array}{l}\text { 流 } \quad \text { 下 率 } \\
G[n \rightarrow(n+1)) \%\end{array}$} & \multicolumn{2}{|c|}{$\begin{array}{c}\text { 単独発生率 } \\
\mathrm{p}_{0} \text { (n) \% }\end{array}$} \\
\hline & $N(0) / N(1)$ & $N(1) / N(2)$ & $P(0)$ & $P(1)$ & $P(2)$ & G $(0 \rightarrow 1)$ & G $(1 \rightarrow 2)$ & $p_{0}$ (1) & $p_{0}$ (2) \\
\hline 有野川 & 4.4 & 4.3 & 8.4 & 16.0 & 19.4 & 85 & 80 & 2 & 0 \\
\hline 芦昆川 & 5.3 & 4.6 & 3.9 & 8.0 & 13.5 & 91 & 89 & 3 & 2 \\
\hline 住吉川 & 4.5 & 4.9 & 11.9 & 23.4 & 49.3 & 80 & 84 & 5 & 11 \\
\hline 西郎 川 & 4.8 & 3.2 & 15.3 & 23.3 & 42.9 & 83 & 82 & 5 & 0 \\
\hline 宇治川 & 4.8 & 4.4 & 22.8 & 35.6 & 67.7 & 81 & 88 & 7 & 7 \\
\hline 平均他 & 4.8 & 4.3 & 12.5 & 23.3 & 38.6 & 84 & 85 & 4 & 4 \\
\hline
\end{tabular}

$n: n$ 次渓流

$P_{(0)}$ ：0 次崩壊発生率 $(0$ 次渓流での崩壊数 $/ 0$ 次 溪流数)

有野川については柴小場堰堤上流域のデータ。 西郷川については青谷のデータ。
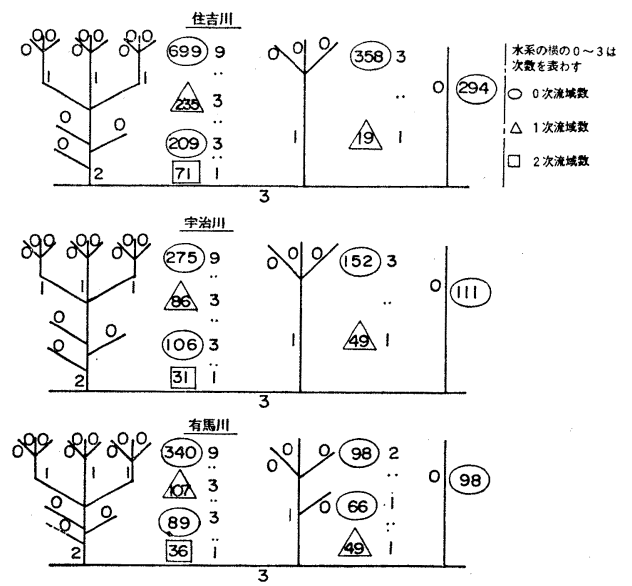

図-15 六甲山地における水系分岐パターン

ある。この比率は通常の分岐比 ${ }^{4)} 25: 5: 1$ 飞皃近 い数值となっている。この分岐比は 5 本の 1 次水系（渓 流）が1本の 2 次水系（渓流）飞連続していることを意 味するのではなく，あくまで流域全体の相対的比率を示 し，実際の水系分岐パターンは図-15 のごとくとなって いる。

代表 5 河川に特ける水系パターン上で，土石流の発 生，流下様式を検討すると表-1 のようになる。ここで， 0 次渓流については，土石流発生と崩壊発生を同一飞扱 い，1 次溪流に扣汀る土石流発生の定義は，2 次溪流に ついてと同様に，渓流下流端で土砂の移動した痕跡が認 められた場合を発生とする。発生率 $P_{(n)}$ とは $n$ 次の渓 
流本数 $N_{(n)}$ のらち何 \% の渓流本数で土石流が発生し ているかを表す。この発生した土石流は，0次渓流から 1 次渓流， 1 次渓流から 2 次渓流へと連続して流下して いる。今， $n$ 次渓流で発生した土石流のらち何 \% が, $(n+1)$ 次渓流に連続して流下・発生しているかを流下率 $G$ と定義し，各流域で計測すると 表-1 に示すようにほ ぼ一定の流下率 $G[0 \rightarrow 1]=84 \%, G[1 \rightarrow 2]=85 \%$ に なる。また，上流（低次渓流）からの流入がない土石流 の発生を単独発生とし, 発生率と同じように単独発生率 $p_{0(n)}$ を定義すると, 表-1 のごとくなる〔 $P_{(0)}=p_{0(0)}$ と なる]。ここでいう単独発生は, 高橋のいう渓床堆積物 上に表面流が生じて発生する土石流パターンヅに近いも のであろう。

ここで, $(n+1)$ 次渓流に括ける土石流発生本数は $N_{(n+1)} \cdot P_{(n+1)}$ であるが, これと単独発生率, 流下率を 使って $N_{(n+1)} \cdot P_{(n+1)}$ を表すと,

$$
\begin{aligned}
& N_{(n+1)} \cdot P_{(n+1)}= p_{0(n+1)} \cdot N_{(n+1)}+N_{(n)} \cdot P_{(n)} \\
& \cdot G[(n) \rightarrow[n+1)] \cdot X_{(n+1)}
\end{aligned}
$$

となる，但し， $X_{(n+1)}$ を谷分岐パターンに関する補正 係数とする。

両辺を $N_{(n+1)} \cdot P_{(n)}$ で除すと,

$$
\begin{aligned}
& \frac{P_{(n+1)}}{P_{(n)}}=\frac{p_{0(n+1)}}{P_{(n)}}+\frac{N_{(n)}}{N_{(n+1)}} \\
& \cdot G[(n) \rightarrow(n+1)] \cdot X_{(n+1)} \cdots
\end{aligned}
$$

となる。ここで補正係数 $X_{(n+1)}$ は, 六甲山地の場合 $X_{(1)}=0.38, X_{(2)}=0.41$ となる。このように0次渓流に 扣ける崩壊発生率 $P_{(0)}$ および単独発生率 $p_{0(n+1)}$ が与 兄れれば，(2) 式により1次渓流の，さらに 2 次渓流 の土石流発生率が確定することとなる。

\section{6. まとめ}

本論文では，昭和 42 年 7 月に六甲山地で発生した土 石流を対象に, 発生条件としての地形, 地質特性につい て考察し，土石流の流下様式に一定の規則性があること を示した。これ等の結果をまとめると以下のようにな る。

1） 2 次の渓流で土石流が発生し易くなる地形特性を 列記すると以下のようになる。ただし，これ等単独 では土石流の発生・非発生を判別する有効な特性と ならない。

○流域面積が 5〜10 ha 以上となる。

○主流路の平均勾配が $16^{\circ} \sim 18^{\circ}$ 以上となる。

。流域内の最高と最低の標高差が $150 \sim 200 \mathrm{~m}$ 以上
となる。

○渓流内の 0 次谷数が $20 \sim 30$ 本以上になる。

2） 2 次の渓流で土石流が発生し易くなる地質特性を 列記すると以下のようになる。ただし，これ等単独 では土石流の発生・非発生を判別する有効な特性と ならない。

○布引花崗閃緑岩が分布する。

○リニアメントが流域内に 3 本以上ある。

。秃赫地・岩塔が存在する。

。深層風化帯の分布が, 渓流内の上流域にある。

3）今回取扱った要因は全て 2 次渓流の平均的特性で あり，直接的に土石流発生と結びっくものではな く，土石流発生の器としての特性を明らかにしたも のである。同一の器の中で土石流は繰り返し発生す るものであろらから, やはり渓床堆積物のあり方を 議論すべきである。今回は航空写真判読上の制約で 堆積物のあり方と土石流との関係については考察し なかったが，今後の課題である。

\section{7. 謝辞}

本研究には，建設省六甲砂防工事事務所で実施された 調査結果の一部を使用させて頂きました。資料の使用に ついて御配慮賜った，成田久夫元所長，堀内成郎元調査 係長に深く感謝の意を表わします。

京都大学農学部武居有恒教授には終始懇切丁寧な御助 言，御指導を賜りました。ここに深く感謝申しあげま す。大阪市立大学平野昌繁助教授には，地形，地質特性 の記載, 特にリニアメントの判読には直接御協力いただ きました。ここに感謝の意を表わします。

本論文をまとめるに際しては，広島大学柿谷悟教授， 竹野節夫助教授に御助言，御指導を賜りました深く感謝 致します。

\section{参考 文 献}

1）藤田和夫 (1983)：日本の地形形成論, 蒼樹書房 pp. $168-169$

2）建設省六甲砂防工事事務所（1974）：六甲三十年 史

3）神戸市企画局（1971)：六甲山地とその周辺の地 質

4）高山茂美（1974）：河川地形，共立出版， p. 23， p. 25

5）武居有恒 (1982)：地すべり・崩壊・土石流——予 測と対策一，鹿島出版会，pp. 158-191

6）建設省国土地理院（1966）：土地条件調査報告書 「京都，播磨地域」，付図-32 
7) 柿谷悟 (1974): 広島県における花菵岩の風化 と地形, 地理科学, 21 号, pp. 1-10

8）芦田和男, 高橋保, 道上正規 (1983): 河川の土 砂災害と対策，森北出版，pp. 55-60

9）高橋 保 (1978)：土石流の発生と流動の機構, 土と基礎，26-6（244）, pp. 45-50

10）建設省吉野川砂防工事事務所，砂防地すべり技術 センター（1976）：仁淀川土砂害対策調査報告書

11）建設省六甲砂防工事事務所 $(1977,78)$ ：六甲山系 土石流危険渓流区域調查業務報告書

12）斉藤金一郎，浅井 晃 (1951)：標本調査の設計，
培風館, pp. 45-48

13）建設省河川局砂防部（1978）：土石流危険溪流お よび危険区域調査要領(案)

14）、小橋澄治, 武居有恒, 仲野公章 (1977)：土石流 発生の場とその条件 (2)，新砂防 106，No. 3, pp. 1-6

15）低引洋隆, 小橋澄治, 武居有恒, 平野昌繁, 今西 欣也 (1978)：六甲山系土石流災害の検討（2）, 昭和 53 年度砂防学会研究発表会概要集, pp. 102103

(昭和 60 年 12 月 27 日受付, 昭和 61 年 6 月 3 日受理) 